\section{The Effect of Relationship Characteristics on Buying Fresh Flowers as Romantic Valentine's Day Gifts}

\author{
Yen-Chun Lai and Li-Chun Huang ${ }^{1}$
}

ADDITIONAL INDEX WORDs. floral gifts, floral market, gift giving, multinomial logistic regression analysis, people-plant interaction

\begin{abstract}
SUMMARY. A high percentage of fresh flowers sold are consumed as gifts in many countries, such as Taiwan, Japan, and the United States. As gift consumption is so important for the sales of fresh flowers, consumer behavior in floral gift giving is investigated in this research. This study explored the consumer decision to purchase fresh flowers as a romantic gift for Valentine's Day based on 1) relationship stage, 2 ) affection, and 3 ) satisfaction with the relationship. The statistical results, based on the data of 366 valid questionnaires collected from a self-administered questionnaire survey, showed that the relationship stage of "personality need fulfillment," the affection of "passion," and relationship satisfaction significantly influenced the consumer decision of whether to purchase fresh flowers as romantic Valentine's Day gifts. Consumers were more likely to buy their intimate partners fresh flowers when they perceived their personality need, such as the need of being loved, was fulfilled in the relationship. When strongly passionate about that relationship, they tended to give fresh flowers in conjunction with other gifts. However, when consumers were more satisfied with their romantic relationships, they were less likely to buy their intimate partners fresh flowers. The study results have valuable implications for florists' business alliances and advertising campaign development for promoting floral gifts efficiently.
\end{abstract}

$\mathrm{F}$ lowers play an important role in social life being frequently used to mark significant occasions in life, such as holidays, weddings, births, and deaths. Because of their symbolic meanings, usually grounded in their appearance, color, fragrance, growing seasons, or stories, flowers are also used as gifts to convey the givers' intentions to the receivers [Connolly, 2004; Seaton, 1995; Society of American Florists (SAF), 2012a]. In fact, gift giving today has become the primary reason for fresh flower purchases. In the United States, 67\% of fresh flower purchases are for gifts (SAF, 2012b). In Japan, $80 \%$ of cut flowers are consumed as gifts or for commercial purposes, while $60 \%$ of potted plants are purchased as gifts in Korea (Kim et al., 1999). Even though purchasing flowers as a gift is important, consumer behavior related

Department of Bio-Industry Communication and Development, National Taiwan University, Taipei 10617 , Taiwan

This study was funded by the National Science Council of Taiwan (101-2410-H-002-192).

We thank Dr. Neal E. De Vos, Dr. Charles R. Hall, and the anonymous reviewers for their review and insightful comments on an earlier version of this manuscript.

${ }^{1}$ Corresponding author. E-mail: lihuang@ntu.edu.tw. to this action has rarely been the focus of academic studies. This study is intended to address this deficiency.

When purchasing flowers as gifts, consumers like to buy the flowers in person because they enjoy the sensory pleasure derived from their beauty and fragrance. Consumers also want the floral gifts to have good blooming quality and longevity because they hope to maximize their purchase value and increase the remembrance of their gifts (Yue et al., 2009). Basically, floral gift purchases are highly occasion oriented. Christmas, Mother's Day, Valentine's Day, and birthdays are among the most common occasions for purchasing flowers for gifts. Of these holiday occasions, Valentine's Day is the most important for the retailing of floral gifts, accounting for $40 \%$ (in dollar volume) of the total fresh flower holiday sales in the United States (SAF, 2012c).

Valentine's Day is a highly commercialized holiday for gift giving worldwide (Clark et al., 1999). On average, every couple in the United States spent about US\$68.98 on their romantic partners for Valentine's Day in 2011 (Grannis, 2011); the average annual sales volume of Valentine's
Day gifts in Taiwan is about US\$118.8 million (Eastern Online, 2006), averaging US\$9.9 per capita. Even though flowers have been shown to be helpful for facilitating a romantic relationship (Guéguen, 2011, 2012), statistical reports on Valentine's Day gift sales show that flowers are not the most favorite gift choice on this occasion. For example, a statistical report in the United States in 2005 showed that jewelry, candy, and apparel, rather than flowers, were the top three gift choices for Valentine's Day (SAF, 2005). Similarly for Taiwan, flowers ranked third, after apparel and chocolate, as the favorite romantic gift purchases for Valentine's Day (Eastern Online, 2005). Obviously, florists have strong competition on Valentine's Day.

Gifts are mainly used for social communication. They work as an instrument to convey the giver's intention, as well as how the giver perceives the recipient and the relationship (Banks, 1979; Belk and Coon, 1993; Joy, 2001; Schwartz, 1967). On the recipient side, accepting gifts means agreeing with the giver's intention and identification (Belk and Coon, 1993; Schwartz, 1967). Thus, through the action of gift giving, the intentions between the dyad are communicated, and the relationship is initiated or realigned.

Gifts are highly diverse and include both tangible and intangible objects, such as service, time, ideas, or even money (Belk and Coon, 1993; Joy, 2001). However, what is given as a gift is determined by the characteristics of the relationship, such as the development and intimacy level of the relationship (Belk and Coon, 1993; Burgoyne and Routh, 1991; Komter and Vollebergh, 1997). Romantic gift giving tends to follow the same rule. For example, even though gift giving is a common strategy for initiating a romantic relationship at the early stage of dating, men prefer to choose symbolic gifts, instead of expensive ones, to express their feelings for their dating partners (Coon and Belk, 1991). This is in part to avoid being taken advantage of, as well as to maximize the marginal value of dating gifts. In contrast, gifts for intimate partners tend to be more expensive and practical in a marital relationship (Clark et al., 1999; Coon and Belk, 1991). 
According to the wheel theory of love (Reiss, 1960, 1976; Reiss and Lee, 1988), there are four stages in the development of a romantic relationship: rapport, self-revelation, mutual dependency, and personality need fulfillment. For each stage, different motivations and affection are fostered and experienced, and the intimacy level varies across these stages. At the beginning, a mutual feeling of rapport is perceived, and the couple feels familiar, comfortable, and relaxed with each other, and has the desire to disclose him/herself more to the other. If the individual discloses him/herself to the one admired, then the relationship moves to the next stage, self-revelation (Reiss, 1960, 1976; Reiss and Lee, 1988). With the increase of sharing experiences and knowing each other's inner self as a result of this self-disclosure, an interdependent habit system is built between the partners, and the relationship becomes closer and more intimate. This is known as the mutual dependency stage. As the relationship continues, certain inner needs are fulfilled, the two have the emotional feelings of belonging, trust and being encouraged, and they feel they can sacrifice for each other. These four stages proceed from one to the next sequentially, and the process circulates from the first stage to the last repeatedly like the movement of a wheel or clockspring (Borland, 1975 ), as the romantic relationship continues. Reiss's wheel theory is one of the pioneer theories in romantic love paving a way for researchers to see how romantic relationships form and progress. This theory has been widely applied by researchers to test their research hypotheses or support their research findings (HaavioMannila and Rannik, 1987; Lewis, 1973; Martin and Luke, 1991; Ridley et al., 1982), as well as widely cited by contemporary researchers to define the development of romantic love (Atwood, 1994; Cere, 2000; Hazan and Shaver, 1994; Määttä and Uusiautti, 2012; Paik and Woodley, 2012; Sassler, 2004).

The affection and intimacy level of a romantic relationship will depend on the number of cycles that the "love wheel" has passed through (Borland, 1975; Reiss, 1960, 1976; Reiss and Lee, 1988), even though the development of romantic love is a reversible process (Borland, 1975). The triangular love theory proposed by Sternberg $(1986,1997)$ defines three affection components for romantic love: intimacy, passion, and commitment. The intimacy component refers to the feelings of closeness in a love relationship that usually generate the experience of warmth for the person in love. The passion component refers to the physical attraction and sexual consummation, or other phenomena related to the intensity or arousal of the inner sexual drive. The commitment component refers to the cognitive decision to stay in the relationship long term. The conceptualization of triangular love theory (Sternberg, 1986, 1997) has been widely adopted by many contemporary researchers to measure interpersonal romantic love (Aloni and Bernieri, 2004; Arias et al., 2009; Barelds and Barelds-Dijkstra, 2007; Bauermeister et al., 2011; Engel et al., 2002; Zeidner and Kaluda, 2008). Some researchers have extended the triangular love scale to measure consumers' love for brands, products, or firms (Albert and Valette-Florence, 2010; Jin and Jia, 2009; Yim et al., 2008), as well as people's religious love of God (Beck, 2006).

Generally, the strength and balance of the love affections verify an individual's experience and behavior in a romantic relationship. However, what kind of love is experienced partly depends on an individual's romantic attachment style, an inner personality characteristic (Feeney and Noller, 1992; Tucker and Anders, 1999). Those who are anxious about their romantic relationship worry about being betrayed or neglected, and thus constantly monitor their intimate partners. Some others may have an avoidant attitude to love, such that they are afraid to have a promised relationship with others, and thus tend to avoid commitment in the relationship (Feeney and Noller, 1992; Nguyen and Munch, 2011; Tucker and Anders, 1999). Frankly, individuals tend to have different expectations for their romantic relationships. So, even though love has its sweetness, not everyone wishes to say "I love you" or look for commitment in a romantic relationship for various reasons, such as obligation, anxiety, and materialism (Belk and Coon, 1993; Otnes et al., 1994). As gifts may influence relationships, an individual's satisfaction level toward his/her romantic relationship is very likely to influence his/her gift-giving behavior in the relationship.

As flowers are usually positioned as "expressive" products by florists to encourage consumers to buy flowers as romantic gifts, understanding how the characteristics of a romantic relationship influence consumers' choice of whether to buy flowers as romantic gifts will help florists in promoting flowers on Valentine's Day more efficiently. This study was aimed to explore the influence of the characteristics of a romantic relationship, in terms of its development stages, affection components, and satisfaction level on consumers' decisions of whether to buy their intimate partners a gift of fresh flowers for Valentine's Day. The study results can benefit the floral industry in developing advertising campaigns and alliances for promoting Valentine's Day floral gifts more efficiently.

\section{Materials and methods}

SAMPLING. The survey took place in Taipei, Taichung, and Kaohsiung, which are the main cities located in the north, center, and south of Taiwan. The participants were approached at shopping malls, theaters, gasoline stations, and post offices. Most of them spent $\approx 10$ to 15 min filling out selfadministered questionnaires. After completing the questionnaires, the participants received a purchase voucher, which had a face value of NT\$50 [New Taiwanese Dollar (equivalent to $\$ 1.72$ )], for use at a famous fast food chain store as the reward for their participation.

To recruit consumers who bought their romantic partners gifts on Valentine's Day, the sample was surveyed with a purposive sampling strategy. The potential participants were filtered first with the question "did you buy your girlfriend, boyfriend, or spouse a gift for Valentine's Day this year?" Once individuals said they had, they were invited to participate in the survey. The survey took place during the time period from $22 \mathrm{Apr}$. to 29 May 2011 , about two to three months after Valentine's Day, to ensure that the participants could recall their romantic gift giving vividly to provide this study with accurate information. 
A total of 384 consumers participated in this study, but 18 questionnaires were invalid since they were filled out by individuals under 18 years old, not the targeted consumer group for this study. As a result, a total of 366 questionnaires were valid for the statistical analysis.

Questionnaire Design. A questionnaire was developed as the instrument of data collection. All the scale items used in this study were modified from theoretical conceptualizations or scales whose validity has been proven by previous studies. Details of the scale items are illustrated in Tables 1-3 for each variable, including the statements and reliability indicated with Cronbach's $\alpha$. A pilot study completed with 12 college students was conducted on 15 Apr. 2011 to test the reliability and comprehensibility of the scale items. The 12 college students were all 18 years old or older, representative of the age of the target demographic for this study.

The development stage of the participants' romantic relationship before the presentation of their romantic Valentine's Day gifts was measured in terms of rapport, self-revelation, mutual dependency, and personality need fulfillment, based on the wheel theory of love (Borland, 1975; Reiss 1960, 1976; Reiss and Lee, 1988). Scale items for each love stage were modified from the theoretical conceptualization of this theory. Reiss's wheel theory of love has been widely adopted in studies of romantic love. For example, the development framework accounting for premarital dyadic formation proposed by Lewis (1973) was grounded in the framework of the wheel theory; Haavio-Mannila and Rannik (1987) used the wheel theory of love to investigate the differences in marital love between Estonia and Finland; Martin and Luke (1991) also used Reiss's theory to investigate the reasons for falling out of love. Besides being used to test research hypotheses, it also has been used by many contemporary researchers to support research findings or define the development of romantic love, like Atwood (1994), Cere (2000), Haavio-Mannila and Rannik (1987), Määttä and Uusiautti (2012), Paik and Woodley (2012), Ridley et al. (1982), as described above.

The participants were asked to recall their romantic relationship and indicated their levels of agreement with the statements of the scale items with a five-point Likert scale. Scale reliability was at a satisfactory level for each stage variable [Cronbach's $\alpha \geq$ 0.70 (Hair et al., 2010)] except mutual dependency (Table 1 ). The results of the pilot study showed poor reliability for the scale items composed for the measure of mutual dependency (with a Cronbach's $\alpha$ of 0.46 ). After revision, the reliability increased to a Cronbach's $\alpha$ of 0.63 , a moderately acceptable level from a statistical perspective (Hair et al., 2010). If the item "She/he fulfilled my sexual need" was removed from the scale set, the reliability for the measurement of mutual dependency increased to a higher level of Cronbach's $\alpha(0.75)$. However, sexual intimacy is an important indicator of the development stage of mutual dependency in a romantic relationship (Reiss, 1960, 1976; Reiss and Lee, 1988). After weighing the importance of measurement reliability for the variable and considering that a Cronbach's $\alpha$ of 0.63 is an acceptable level for the internal reliability of scale items, the researchers decided to keep the item "she/he fulfilled my sexual need" to increase the discrimination power of the scale items.

There were 36 scale items modified from the triangular love scale proposed by Sternberg (1997) to measure the love components (i.e., intimacy, passion, and commitment) that the participants had in their romantic relationships (Table 2 ). The participants were asked to recall their love relationships with their intimate partners for the time near the last Valentine's Day and to indicate their agreement on these measurement items with a five-point Likert scale. The triangular love scale has been widely used to measure interpersonal romantic love (Aloni and Bernieri, 2004; Arias et al., 2009; Barelds and Barelds-Dijkstra, 2007; Bauermeister et al., 2011; Engel et al., 2002; Zeidner and Kaluda, 2008) and has been proven valid for contemporary romantic

Table 1. The statements and reliabilities of the scale items used in a study to examine the development stage of participants' romantic relationship in terms of rapport, self-revelation, mutual dependency, and personality need fulfillment via a consumer survey conducted in Taipei, Taichung, and Kaohsiung, Taiwan from 22 Apr. to 29 May 2011. The survey explored the effect of the development stage, affection, and satisfaction of a romantic relationship on the purchase decision of buying fresh flowers as a romantic gift for Valentine's Day.

\begin{tabular}{llc}
\hline Variable & \multicolumn{1}{c}{ Scale item } & Cronbach's $\alpha$ \\
\hline Rapport & 1) I felt quite at ease whenever with her/him. & 0.80 \\
2) I was often hoping to learn more about her/him. & \\
3) I often felt like I have known her/him for & a long time. \\
4) I felt she/he is worthy of respect. & 5) I felt she/he is worthy of trust.
\end{tabular}

Self-revelation 1) I often shared my emotions with her/him.

0.86

2) I often disclosed my privacy to her/him.

3) I often shared what is important to me with her/him

4) I often shared my deepest feelings with her/him.

5) I didn't worry about her/him knowing my bad habits.

$\begin{array}{lll}\text { Mutual } & \text { 1) I needed her/him to share my ideas or feelings. } & 0.63\end{array}$

dependency 2) I needed her/him to joke with.

3) She/he fulfilled my sexual need.

Personality need 1) She/he loved me. fulfillment

2) I often confided in her/him.

3) She/he often showed her/his deep love for me.

4) She/he always understood my moods.

5 ) She /he often encouraged me to make progress.

6) She/he made me felt confident. 
Table 2. The statements and reliabilities of the scale items used in a study to examine participants' love affection of intimacy, passion, and commitment via a consumer survey conducted in Taipei, Taichung, and Kaohsiung, Taiwan from 22 Apr. to 29 May 2011. The survey explored the effect of the development stage, affection, and satisfaction of a romantic relationship on the purchase decision of buying fresh flowers as a romantic gift for Valentine's Day.

\begin{tabular}{|c|c|c|}
\hline Variable & Scale item & Cronbach's $\alpha$ \\
\hline Intimacy & $\begin{array}{l}\text { 1) We had a warm and comfortable relationship. } \\
\text { 2) Our relationship was very intimate. } \\
\text { 3) I was strongly motivated to make her/him happy. } \\
\text { 4) We knew each other quite well. } \\
\text { 5) She/he was the main emotional support to me. } \\
\text { 6) I was able to count on her/him whenever } \\
\text { I needed help or support. } \\
\text { 7) She/He was also able to count on me whenever } \\
\text { she/he needed help or support. } \\
\text { 8) I saw her/him as great value in my life. } \\
\text { 9) I was willing to share all I had with her/him. } \\
\text { 10) Nothing could make me happier than being } \\
\text { with her/him. } \\
\text { 11) We were emotionally close to each other. } \\
\text { 12) I gave considerable emotional support to her/him. }\end{array}$ & 0.95 \\
\hline
\end{tabular}

Passion 1) I could not imagine there was any other person who could make me as happy as she/he did.

2) There was nothing important to me except her/him.

3) Our relationship was very romantic.

4) I could not imagine how my life would be without her/him.

5 ) I was obsessed with her/him deeply.

6) My mind was occupied by her/him at the time.

7) I felt excited whenever we met.

8) She/he was very sexy to me.

9) She/he was my idol.

10) Our relationship was meant to be.

11) I always felt our relationship was fresh.

12) I liked to give her/him gifts at the time.

Commitment 1) I felt a strong responsibility for her/him.

2) I hoped our love lasted eternally.

3) I felt I couldn't live without her/him.

4) I saw our relationship as lifelong.

5) I was willing to stand by her/him to help her/him go through the most difficult time.

6) I promised to keep my word to her/him.

7) I never doubted my love to her/him.

8) I decided to love her/him.

9) I always did my best to maintain our love relationship.

10) Our love relationship was a thought-out decision, not blind.

11) I protected our relationship with every bit of my life.

12) I was very confident about our relationship.

relationships (Bauermeister et al., 2011; Graham and Christiansen, 2009). In this study, the internal reliability of the scale items was good with a Cronbach's $\alpha$ of at least 0.94 for all the variables of love affection (Hair et al., 2010). a romantic relationship (Cann et al., 2011; Humphreys et al., 2009; Renshaw et al., 2011; Schröder-Abé and Schütz, 2011; Stackert and Bursik, 2003; van Dulmen and Goncy, 2010). The validity and reliability of the RAS has been tested, and it has been proven to show good psychometric properties (Hendrick et al., 1998; Vaughn and Baier, 1999). In the same way, the participants were asked to recall their romantic relationships for the time near last Valentine's Day and then indicate their agreement with the scale items using a five-point Likert scale. The internal reliability for these scale items was at a satisfactory level [Cronbach's $\alpha \geq 0.70$ (Hair et al., 2010)].

The scale listed in the fourth section of the questionnaire was aimed to identify the gifts that the participants have presented to their intimate partners on the last Valentine's Day. This scale measured the participants' gift choice in three categories: a gift of fresh flowers only, fresh flowers plus other nonfloral gifts, and a gift of anything except flowers. Once the participants indicated they have given any nonfloral gifts (i.e., either along with flowers or alone without flowers), they were asked to identify their nonfloral gift items from a gift list provided on the questionnaire. The gift list included the nonfloral gift items reported as the most popular Valentine's Day gifts in Taiwan, including jewelry, chocolate, cards, clothing, flowers, cosmetics or perfume, stuffed animals, handmade gifts, cakes, cash, and gift vouchers (Eastern Online, 2001).

Scale items in the fifth section of the questionnaires were used to measure the participants' demographic characteristics, including gender, age, occupation, monthly income, and highest education level. All of the demographic data, except for age, were measured with category scales. Age was measured with an open scale as the participants were asked to write down their age numerically.

Statistical analysis. All statistical analyses were processed with SPSS (version 17.0; IBM Corp., Armonk, NY). Descriptive statistics regarding the distribution of the 366 participants' demographic characteristics were analyzed to profile the 
sample. Multinomial logistic regression analysis was used to evaluate the influence of the development stage, affection, and satisfaction level of a romantic relationship on the purchase decision of whether to buy fresh flowers as a romantic gift on Valentine's Day.

Multinomial logistic regression analysis is an analytical technique used for investigating the relationship between several metric independent variables and a categorical dependent variable (Hair et al., 2010). The statistical logic of multinomial logistic regression analysis is that the logits of the odds ratios between two outcome categories of a dependent variable are in a linear function to the independent variables (Hilbe, 2009; Kleinbaum et al., 2008). If there are $n$ outcome categories in the dependent variable, there will be a total of $(n-1)$ logits regression equations in the whole multinomial regression model. Assuming there are $p$ number of independent variables $\left(\boldsymbol{x}_{p} s\right)$, then the logit of $P(y=j)$ vs. $P(y=i)$ is in a linear function to the independent variables $x_{p}$ s. It can be summarized as (Hosmer and Lemeshow, 2000; Kleinbaum et al., 2008)

$$
\begin{aligned}
g_{j}(x)= & \ln \left[\frac{P(y=j)}{P(y=i)}\right] \\
= & \beta_{j 0}+\beta_{j 1} x_{1}+\beta_{j 2} x_{2} \\
& +\beta_{j 3} x_{3}+\ldots+\beta_{j p} x_{p}
\end{aligned}
$$

where

$g_{j}(x)$ : the logit functions of the odds ratios between two outcome categories $(j$ and $i$ ) of a dependent variable $(y)$

$P(y=i)$ : the conditional probability of the dependent outcome in the outcome category $i$

$P(y=j)$ : the conditional probability of the dependent outcome in the outcome category $j$

$\beta_{i s}$ : the parameters for interpreting the ratio of the probability of outcome category $j[P(y=j)]$ vs. that of the baseline category $i[P(y=i)]$

Coefficients in the logit equations allow for interpretation of the odds of each outcome category in a dependent variable; that is, the exponentiation of the estimated coefficients explains the amount of change in odds ratios of outcome categories vs. the baseline category for each unit change in the relevant independent variable (Hosmer and Lemeshow, 2000).

\section{Results and discussion}

Portrait of sample. Table 4 summarizes the demographic characteristics of the sample. Among the 366 valid participants, $53.3 \%$ were male and $46.7 \%$ were female. The age distribution was mostly in the range of 26-35 years old (44.0\%). Most participants reported their highest education level as being college degree $(57.9 \%)$ and had an occupation in

Table 3. The statements and reliabilities of the scale items used in a study to measure participants' level of satisfaction with their romantic relationships via a consumer survey conducted in Taipei, Taichung, and Kaohsiung, Taiwan from 22 Apr. to 29 May 2011. The survey explored the effect of the development stage, affection, and satisfaction of a romantic relationship on the purchase decision of buying fresh flowers as a romantic gift for Valentine's Day.

\begin{tabular}{llc}
\hline Variable & \multicolumn{1}{c}{ Scale item } & Cronbach's $\alpha$ \\
\hline Relationship & 1) She/he often satisfied my needs. & 0.78 \\
satisfaction & 2) I was satisfied with our relationship. & \\
& 3) I felt our relationship was close and good & \\
compared with most others. & \\
& 4) I often wished I hadn't gotten into this \\
& relationship at that time. \\
& 5) Our relationship met my expectation very well. \\
6) I loved her/him very much. & \\
7) There were some problems in our relationship. &
\end{tabular}

Table 4. The demographic distribution of the participants based on the data from 366 valid questionnaires sampled from Taipei, Taichung, and Kaohsiung, Taiwan from 22 Apr. to 29 May 2011. The survey explored the effect of the

\begin{tabular}{|c|c|c|}
\hline \multicolumn{2}{|c|}{ Demographics } & Total $(\%)$ \\
\hline \multirow[t]{2}{*}{ Gender } & Male & 53.3 \\
\hline & Female & 46.7 \\
\hline \multirow{5}{*}{ Age (years) } & $18-25$ & 29.8 \\
\hline & $26-35$ & 44.0 \\
\hline & $36-45$ & 13.9 \\
\hline & $46-55$ & 9.6 \\
\hline & More than 55 & 2.7 \\
\hline \multirow[t]{4}{*}{ Education } & Junior high & 1.6 \\
\hline & Senior high & 25.1 \\
\hline & College/university & 57.9 \\
\hline & Graduate school & 15.3 \\
\hline \multirow[t]{8}{*}{ Occupation } & $\begin{array}{l}\text { Agriculture, forestry, fishing, } \\
\text { and animal husbandry }\end{array}$ & 0.8 \\
\hline & Manufacturing & 12.3 \\
\hline & Business/service & 45.6 \\
\hline & $\begin{array}{l}\text { Civil servant, military service, } \\
\text { and education }\end{array}$ & 19.4 \\
\hline & Students & 17.2 \\
\hline & Retired & 0.8 \\
\hline & Housekeeping & 1.9 \\
\hline & Others & 1.9 \\
\hline \multirow{5}{*}{$\begin{array}{l}\text { Income (New Taiwanese } \\
\text { Dollars) }\end{array}$} & Less than 25,000 & 34.4 \\
\hline & $25,001-45,000$ & 36.1 \\
\hline & $45,001-65,000$ & 22.7 \\
\hline & $65,001-85,000$ & 4.4 \\
\hline & More than 85,000 & 2.4 \\
\hline
\end{tabular}
development stage, affection, and satisfaction of a romantic relationship on the purchase decision of buying fresh flowers as a romantic gift for Valentine's Day. 
business or a service industry $(45.6 \%)$. The participants' monthly income was mostly at NT $\$ 45,000$ or less (70.5\%).

The Participants' DeCISIONS ON ROMANTIC VALENTINE'S DAY GIFTS. To avoid statistical bias caused by unequal sample size, even numbers of participants were sampled for each giver category (Hair et al., 2010). As a result, there were 125 participants that gave only fresh flowers to their intimate partners on the last Valentine's Day, classified as "flower givers" in this study. Another 120 participants reported they gave fresh flowers plus some nonfloral gift items to their intimate partners and were classified as "flower and other gift givers." The other 121 participants did not buy their intimate partners any flowers, instead gave nonfloral items, and were classified as "nonfloral gift givers."

For the flower givers, bouquets were the most popular flower gifts; $77.6 \%$ of them purchased a bouquet as a romantic gift on the last Valentine's Day, while $8.0 \%$ of them purchased boxed flowers, $0.6 \%$ a flower basket, $9.6 \%$ potted ornamentals, and $4.8 \%$ stem flowers. For the flower and other gift givers, bouquets were the most popular flower gifts for them too, with $84.2 \%$ purchasing a bouquet as their romantic Valentine's Day gifts. For this group, chocolate, followed by jewelry or a watch, cards, and then apparel, tended to be their most preferred nonfloral gift item paired with their floral gifts. Even though candy is not perceived as the superior gift to reflect givers' personality (Yue et al., 2009), the flower and other gift givers in this study tended to perceive chocolate as the most appropriate gift for pairing their floral gifts for Valentine's Day. Another interesting finding from this group was that they were more likely to give cards to their romantic partners on Valentines' Day compared with the nonfloral gift givers. For the nonfloral gift givers, apparel tended to be their most preferred gift purchase for Valentine's Day, followed by jewelry or a watch and then chocolate or handmade gifts, depending on gender. The female nonfloral gift givers revealed a much stronger tendency to give their sweethearts gifts made by themselves (Table 5 ).

Table 5. The percentage of the nonfloral gifts purchased by survey participants who gave fresh flowers and other nonfloral gifts or whose who gave only nonfloral gifts to their romantic partners for Valentine's Day. Data from 366 valid questionnaires sampled from Taipei, Taichung, and Kaohsiung, Taiwan from 22 Apr. to 29 May 2011.

\begin{tabular}{|c|c|c|c|c|}
\hline \multirow[b]{2}{*}{ Gift item } & \multicolumn{2}{|c|}{ Flower and other gift givers (\%) } & \multicolumn{2}{|c|}{ Nonfloral gift givers (\%) } \\
\hline & $\begin{array}{c}\text { Male } \\
(n=71)\end{array}$ & $\begin{array}{c}\text { Female } \\
(n=49)\end{array}$ & $\begin{array}{c}\text { Male } \\
(n=53)\end{array}$ & $\begin{array}{c}\text { Female } \\
(n=68)\end{array}$ \\
\hline Jewelry/watch & 18.8 & 19.7 & 17.4 & 9.3 \\
\hline Apparel & 15.3 & 14.8 & 26.1 & 26.7 \\
\hline Cosmetics/perfume & 15.3 & 4.9 & 4.3 & 2.7 \\
\hline Chocolate & 18.8 & 32.8 & 14.5 & 14.7 \\
\hline Cards & 16.5 & 14.8 & 10.1 & 9.3 \\
\hline Cash/gift certificate & 1.2 & 6.6 & 4.3 & 8.0 \\
\hline Dinner & 1.2 & 0 & 1.4 & 1.3 \\
\hline Self-made gifts & 4.7 & 6.6 & 5.8 & 14.7 \\
\hline Others $^{z}$ & 8.2 & 0 & 15.9 & 13.3 \\
\hline
\end{tabular}

${ }^{\mathrm{z}}$ Including cakes, toys, fruit, purses, etc.

The Influence OF The RELATIONSHIP CHARACTERISTICS ON THE TENDENCY OF BUYING FLOWERS AS ROMANTIC VALENTINE'S DAY GIFTS. In this section, multinomial logistic regression analysis was applied to evaluate the effects of love development, affection, and satisfaction on the likelihood of buying fresh flowers as romantic Valentine's Day gifts. In the analysis, the probability of the outcome category of "nonfloral gifts" was used as the baseline category to form the logit functions of the multinomial logistic regression model. As presented in Table 6, the statistical results indicated that the independent variables of the "personality need fulfillment" stage of love development, as well as passion and relationship satisfaction revealed significant effects on the decision of whether to buy fresh flowers for Valentine's Day.

Regarding the effect of love development stage, the exponentiation of the estimated regression coefficients (odds ratio) indicated that when an individual perceived that his/her personality needs were more fulfilled in a romantic relationship, the individual would be more likely to buy fresh flowers as a romantic gift for Valentine's Day, rather than any nonfloral gift item [odds ratio $=2.173, P=$ 0.040 (Table 6)]. Meanwhile, flowers tended to be the only gift they gave to their intimate partners, without the pairing of any other gifts.

For the effect of love component, the statistical results indicated that passion was a positive force that drove the participants to buy fresh flowers for Valentine's Day (odds ratio $=3.122, P=0.008)$. For those who revealed strong passion about their romantic relationships, their gifts of flowers were presented in a more luxurious way usually paired with other extra gift items, such as chocolate, apparel, jewelry, etc.

However, the relationship satisfaction was negatively related to the likelihood of buying fresh flowers for Valentine's Day: the more satisfied the participants were with their romantic relationships, the less likely they were to purchase fresh flowers as a romantic gift for Valentine's Day (odds ratio $=0.344, P=0.003$; odds ratio $=0.480, P=0.038$ ).

Even though both "personality need fulfillment" and "passion" were positive forces that encouraged consumers to buy their intimate partners fresh flowers for Valentine's Day, they had different effects on whether the floral gifts were paired with other gift items. Additionally, relationship satisfaction tended to be a problem for the purchase of flowers. This might be explainable from the changes in motivation for romantic gift giving across the course of a romantic relationship, described in the following.

Compared with other love affection, such as intimacy or commitment, passion is a highly motivation-oriented affection driven by the desirability of closeness and sex (Sternberg, 1986, 1997). Because of the strong desire for being together spiritually and physically, individuals who are passionately in love usually have a high demand for relationship commitment (Fisher et al., 2006; Gillath et al., 2008; Sternberg, $1986,1997)$. As gifts are an instrument 
Table 6. Summary of the multinomial logistic regression analysis performed to evaluate the effects of the development stage, affection, and relationship satisfaction of a romantic relationship on the likelihood of buying fresh flowers as romantic Valentine's Day gifts based on 366 valid questionnaires surveyed in Taipei, Taichung, and Kaohsiung, Taiwan from 22 Apr. to 29 May $2011 .{ }^{\mathrm{z}}$

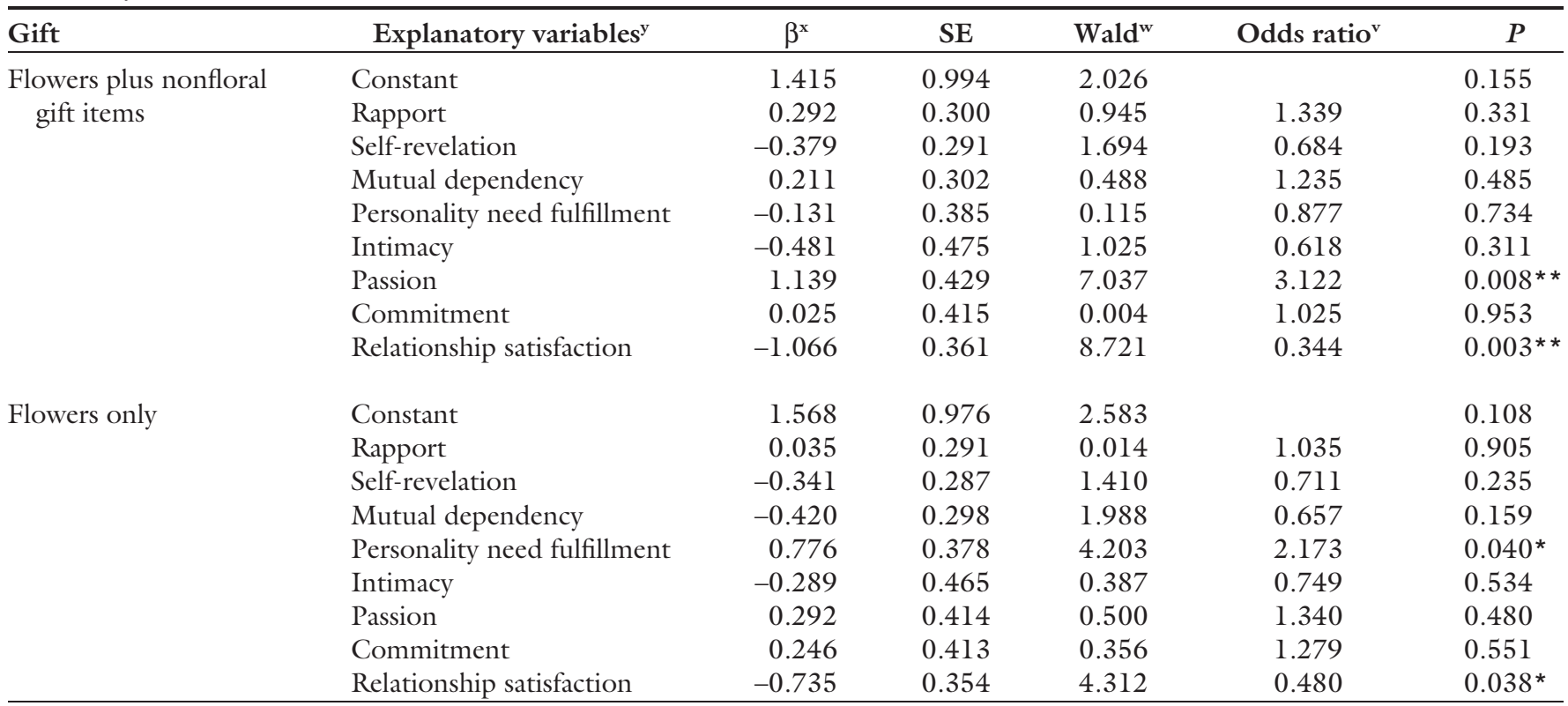

${ }^{\mathrm{z}}$ Overall fit of the multinomial logistic regression model was evaluated with $-2 \log$ likelihood (chi-square $\left.=28.837, P=0.025\right)$, Cox and Snell $R^{2}\left(R^{2} \mathrm{CS}=0.076\right)$, and Negelkerke $R^{2}\left(R^{2}{ }_{\mathrm{N}}=0.085\right)$

All the explanatory variables were measured with a five-point Likert scale ( $5=$ extremely agree, $4=$ agree, $3=$ neutral, $2=$ disagree, $1=$ extremely disagree).

Estimated logistic coefficient.

"Wald statistic, a test used in logistic regression for the significance of the logistic coefficient.

"The category "nonfloral gifts" was used as the reference category.

* ${ }^{*}$ * Significant at $P \leq 0.05,0.01$, respectively.

to convey the givers' intention, once the gifts are selected in a strongly passionate romantic relationship, they will be expected to translate multiple messages to the receivers: not merely to convey the giver's intention of relationship commitment and sex but also to show the recipient the appropriateness and worthiness of the relationship with the giver. Thus, in addition to the conveying of givers' intentions, the gifts selected are also expected to serve as a cue to reflect something that is important for gaining commitment and sexual permission, such as wealth or other possible benefits that the recipients can have from the relationship, to increase the charm of the givers (Belk and Coon, 1993; Close and Zinkhan, 2009; Dunn et al., 2008; Schwartz, 1967). After all, practical value plays an important role in the relationship between men and women (Belk and Coon, 1991, 1993). Even though flowers are a gift that is very expressive of love, it is hard to deny the fact that some consumers perceive flowers as a gift short of utility value (Huang, 2005; Yue et al., 2009). This might make flowers inferior for conveying the intentions embedded in strongly passionate love. In such a circumstance, extra gift items tend to be necessary to build upon the floral gifts to satisfy the needs of the giver who is involved in a romantic relationship with strong passion. As listed on Table 5 , items with high utility function or economic value, such as chocolate, jewelry, clothing, cosmetics, perfume, etc., were preferred as the paired gift items to boost the gift value of flowers. By some consumers' perception, once the floral gifts are paired with other substances, their durability, practicality, and uniqueness are increased (Rihn et al., 2011).

In contrast, the perceptions of personality need fulfillment in a romantic relationship are achieved via the success of self-revelation and mutual dependency system between the dyad involved (Reiss, 1960). Thus, for a romantic relationship at the stage of personality need fulfillment, the relationship has been assured and certain essential elements for the spiritual satisfaction in love, such as caring, trust, respect, and support, have been established between the pair involved (Borland, 1975; Reiss, 1960). As perfect mutual understanding is already there for the dyad in the relationship, a romantic gift no longer needs to bear so many cues for its role-it can be purely expressive. Thus, extra gift items tend to be unessential for the gift of flowers presented by the givers whose romantic relationship has progressed to the stage of personality need fulfillment.

From the perspective of social exchange theory, the more satisfied an individual is, the more likely he or she is to commit to the relationship (Rhoades et al., 2010; Sabatelli, 1988). Once the relationship is satisfactory and committed, expressive gifts, such as fresh flowers, are less needed for expressing love because the love between the dyad is already known (Anderson and Emmers-Sommer, 2006; Olderbak and Figueredo, 2009). Besides, they tend to see each other as soon-to-be family and thus are willing to invest more in the relationship, so valuable, practical or unique gifts are more likely to be given to give economic or material support to the recipient, a way of showing family love (Belk and Coon, 1991, 1993; Olderbak and Figueredo, 2009). Thus, practical or expensive gifts, rather than fresh 
flowers, are preferred in a satisfied romantic relationship, as seen in this study. While men tend to use expensive gifts to show a deeply committed affection to intimate partners, women, in particular married ones, tend to see themselves as the main caregivers of their intimate partners and thus prefer to buy intimate partners practical gifts, such as shirts, vest, and sweaters, rather than fresh flowers (Minowa and Gould, 1999).

\section{Conclusions}

This study demonstrates that consumers' purchasing decisions regarding whether to buy their intimate partners fresh flowers for Valentine's Day are influenced by the characteristics of their romantic relationships. Consumers are more likely to buy fresh flowers as a romantic gift for Valentine's Day when they feel their personality need is fulfilled in the relationship or when they are passionately in love. With strong passion, the gifts of flowers are more luxurious when paired with additional, nonfloral gift items, while flowers tend to be the only gift when givers feel fulfillment in their romantic relationship. Jewelry, watches, apparel, chocolate, and cards are the most popular items to pair with floral gifts to convey givers' passion. However, as consumers become satisfied with their romantic relationships, they become less likely to purchase flowers as a romantic gift for Valentine's Day.

The study results provide valuable information to florists, namely that business alliances with chocolate or jewelry companies could be mutually beneficial for the sales volume of Valentine's Day. Individuals who are passionate toward their intimate partners will likely be interested in both flowers and nonfloral products when selecting a romantic gift for Valentine's Day. So they are a common consumer segment for both business sectors of flowers and other nonfloral gifts, in particular the gifts of chocolate or jewelry, as Valentine's Day comes. Florists can exchange their consumer database with these gift stores to promote their products more efficiently. They can ally in displaying ad banners on each other's websites too to have their commercial information reach really interested consumers. Doing so will enhance the efficiency of consumer communication. According to the theory of selective information perception, even though consumers are exposed to thousands of pieces of information daily, only the information relevant to their needs or interest can gain their attention and be processed. Reaching the right consumer segment is critical for efficient consumer communication (Belch and Belch, 2012).

Furthermore, although it is impossible to measure customers' passion for their lover with a scale when they walk into the store to ask for a gift of flowers for Valentine's Day, the florists can forecast it by asking if the gift of flowers will be paired with other gifts. If the answer is yes, the customer is very likely in a strongly passionate love and will be more willing to expend more money on their gift purchase because of the obsessive and sacrificing nature of passionate love. Then, that is a good time for the florists to introduce higher priced items to these customers. Meanwhile, these customers are also more likely to use cards than other givers. As cards have become an essential accessory in the florist business, the wording or design of the cards should be able to reflect strongly passionate love to satisfy these customers' needs.

This study also points out the challenge of selling Valentine's Day flower gifts to long-lasting couples, particularly the ones for whom passion has faded from their relationship, or those whose relationship has been highly satisfactory and committed, such that the dyad treat each other like family members. When romantic love has turned into family love, practical or expensive gifts are preferred over the gifts of fresh flowers, to give material support to the intimate partners, as an expression of family love (Belk and Coon, 1991, 1993; Olderbak and Figueredo, 2009; Ziegler, 2007). Future research focused on the behavior of floral gift giving of long-term couples is suggested for promoting the gift use of fresh flowers.

\section{Literature cited}

Albert, N. and P. Valette-Florence. 2010. Measuring the love feeling for a brand using interpersonal love items. J. Mktg. Dev. Competitiveness 5(1):57-63.

Aloni, M. and F.J. Bernieri. 2004. Is love blind? The effects of experience and infatuation on the perception of love. J. Nonverbal Behav. 28:287-295.
Anderson, T.L. and T.M. Emmers-Sommer. 2006. Predictors of relationship satisfaction in online romantic relationships. Commun. Studies 57:153-172.

Arias, B., A. Ovejero, and R. Morentin. 2009. Love and emotional well-being in people with intellectual disabilities. Span. J. Psychol. 12:204-216.

Atwood, J. 1994. The mating game. J. Couples Ther. 4:61-87.

Banks, S.K. 1979. Gift-giving: A review and an interactive paradigm. Adv. Consum. Res. 6:319-324.

Barelds, D.P.H. and P. Barelds-Dijkstra. 2007. Love at first sight or friends first? Ties among partner personality trait similarity, relationship onset, relationship quality, and love. J. Soc. Pers. Relat. 24:479-496.

Bauermeister, J.A., M.M. Johns, E. Pingel, A. Eisenberg, M.L. Santana, and M. Zimmerman. 2011. Measuring love: Sexual minority male youth's ideal romantic characteristics. J. LGBT Issues Couns. 5:102-121.

Beck, R. 2006. Communion and complaint: Attachment, object-relations, and triangular love perspectives on relationship with God. J. Psychol. Theol. 34:43-52.

Belch, G. and M. Belch. 2012. Advertising and promotion. 9th ed. McGraw-Hill, New York, NY.

Belk, R.W. and G.S. Coon. 1991. Can't buy me love: Dating, money, and gifts. Adv. Consum. Res. 18:521-527.

Belk, R.W. and G.S. Coon. 1993. Gift giving as agapic love: An alternative to the exchange paradigm based on dating experiences. J. Consum. Res. 20:393-417.

Borland, D.M. 1975. An alternative model of the wheel theory. Fam. Coord. 24:289-292.

Burgoyne, C.B. and D.A. Routh. 1991. Constraints on the use of money as a gift at Christmas: The role of status and intimacy. J. Econ. Psychol. 12:47-69.

Cann, A., C.L. Zapata, and H.B. Davis. 2011. Humor style and relationship satisfaction in dating couples: Perceived versus self-reported humor styles as predictors of satisfaction. Humor 24:1-20.

Cere, D. 2000. The experts' story of courtship. Institute for American Values, New York, NY.

Clark, C.L., P.R. Shaver, and M.F. Abrahams. 1999. Strategic behaviors in romantic relationship initiation. Pers. Soc. Psychol. Bul. 25:709-722.

Close, A.G. and G.M. Zinkhan. 2009. Market-resistance and Valentine's Day events. J. Bus. Res. 62:200-207. 
Connolly, S. 2004. The secret language of flowers: Rediscovering traditional meanings. Rizzoli, New York, NY.

Coon, G.S. and R.W. Belk. 1991. Men and women on dating and gift-giving: Same planet, different worlds. Gender Consumer Behavior 1:94-103.

Dunn, E.W., J. Huntsinger, J. Lun, and S. Sinclair. 2008. The gift of similarity: How good and bad gifts influence relationships. Soc. Cogn. 26:469-481.

Eastern Online. 2001. The most popular Valentine's Day gifts for the office workers (in Chinese). 18 Mar. 2011. <http://www. isurvey.com.tw $/ 3$ _product $/ 1$ _eicp_3. $\operatorname{aspx} />$.

Eastern Online. 2005. Analysis on the behavior of Valentine's Day gift giving (in Chinese). 18 Mar. 2011. <http:// www.isurvey.com.tw/>.

Eastern Online. 2006. Trend analysis of gift market in Taiwan: The change from 2001 to 2006 (in Chinese). 18 Mar. 2011. <http://www.isurvey.com.tw/>.

Engel, G., K.R. Olson, and C. Patrick. 2002. The personality of love: Fundamental motives and traits related to components of love. Pers. Individ. Dif. 32: 839-853.

Feeney, J.A. and P. Noller. 1992. Attachment style and romantic love: Relationship dissolution. Aust. J. Psychol. 44:69-74.

Fisher, H.E., A. Aron, and L.L. Brown. 2006. Romantic love: A mammalian brain system for mate choice. Philosophical Trans. Royal Soc. B 361:2173-2186.

Gillath, O., M. Mikulincer, G.E. Birnbaum, and P.R. Shaver. 2008. When sex primes love: Subliminal sexual priming motivates relationship goal pursuit. Pers. Soc. Psychol. Bul. 34:1057-1069.

Graham, J.M. and K. Christiansen. 2009. The reliability of romantic love: A reliability generalization meta-analysis. Pers. Relatsh. 16:49-66.

Grannis, K. 2011. Love is in the air this Valentine's Day, according to NRF. 25 Sept. 2011. <http://www.nrf.com/modules. php? name = News \&sp_id=1075\&op= printfriendly $/>$.

Guéguen, N. 2011. "Say it with flowers": The effect of flowers on mating attractiveness and behavior. Soc. Influence 6:105-112.

Guéguen, N. 2012. "Say it...near the flower shop": Further evidence of the effect of flowers on mating. J. Soc. Psychol. 152:529-532.

Haavio-Mannila, E. and E. Rannik. 1987. Family life in Estonia and Finland. Acta Sociologica 30:355-369.
Hair, J.F., Jr., W.C. Black, B.J. Babin, and R.E. Anderson. 2010. Multivariate data analysis: A global perspective. 7th ed. Prentice Hall, Upper Saddle River, NJ.

Hazan, C. and P.R. Shaver. 1994. Attachment as an organizational framework for research on close relationships. Psychol. Inq. 5:1-22.

Hendrick, S.S. 1988. A generic measure of relationship satisfaction. J. Marriage Fam. 50:93-98.

Hendrick, S.S., A. Dicke, and C. Hendrick. 1998. The relationship assessment scale. J. Soc. Pers. Relat. 15:137-142.

Hilbe, J.M. 2009. Logistic regression models. CRC Press, Boca Raton, FL.

Hosmer, D.W. and S. Lemeshow. 2000. Applied logistic regression. 2nd ed. Wiley, New York, NY.

Huang, L. 2005. Floral product behaviors and their influence on consumer floral purchase frequency. Hort Technology 15:766-771.

Humphreys, T., L.M. Wood, and J.D.A. Parker. 2009. Alexithymia and satisfaction in intimate relationships. Pers. Individ. Dif. 46:43-47.

Jin, M. and S. Jia. 2009. Developing brand's love to consumer in service: A study of sedan maintenance service brand in China. Proc. Mgt. Serv. Sci. Intl. Conf., Wuhan, China. p. 1-4.

Joy, A. 2001. Gift giving in Hong Kong and the continuum of social ties. J. Consum. Res. 28:239-256.

Kim, H.H., Y.J. Kyung, K. Ohkawa, C.H. Park, and B.H. Kwack. 1999. Flower industry in Korea. Acta Hort. 482:407-414.

Kleinbaum, D.G., L.L. Kupper, A. Nizam, and K.E. Muller. 2008. Applied regression analysis and other multivariable methods. Thomson, Belmont, CA.

Komter, A. and W. Vollebergh. 1997. Gift giving and the emotional significance of family and friends. J. Marriage Fam. 59:747-757.

Lewis, R.A. 1973. A longitudinal test of a developmental framework for premarital dyadic formation. J. Marriage Fam. 35: 16-25.

Määttä, K. and S. Uusiautti. 2012. Loves does not retire - Not even after a half century of marriage. J. Educ. Social Res. $2: 23-39$.

Martin, P. and L. Luke. 1991. Divorce and the wheel theory of love. J. Divorce Remarriage 15:3-22.

Minowa, Y. and S.J. Gould. 1999. Love my gift, love me or is it love me, love my gift: A study of the cultural construction of romantic gift giving among Japanese couples. Adv. Consum. Res. 26:119-124.

Nguyen, H.P. and J.M. Munch. 2011. Romantic gift giving as chore or pleasure: The effects of attachment orientation on gift giving perceptions. J. Bus. Res. 64: 113-118.

Olderbak, S. and A.J. Figueredo. 2009. Predicting romantic relationship satisfaction from life history strategy. Pers. Individ. Dif. 46:604-610.

Otnes, C., J.A. Ruth, and C.C. Milbourne. 1994. The pleasure and pain of being close: Men's mixed feelings about participation in Valentine's Day gift exchange. Adv. Consum. Res. 21:159-164.

Paik, A. and V. Woodley. 2012. Symbols and investments as signals: Courtship behaviors in adolescent sexual relationships. Rationality Soc. 24:3-36.

Reiss, I.L. 1960. Toward a sociology of the heterosexual love relationship. Marriage Fam. Living 22:139-145.

Reiss, I.L. 1976. Family systems in America. Holt, Rinehart and Winston, New York, NY.

Reiss, I.L. and G.R. Lee. 1988. Family systems in America. 4th ed. Holt, Rinehart and Winston, New York, NY.

Renshaw, K.D., P. McKnight, C.M. Caska, and R.K. Blais. 2011. The utility of the relationship assessment scale in multiple types of relationships. J. Soc. Pers. Relat. 28:435-447.

Rhoades, G.K., S.M. Stanley, and H.J. Markman. 2010. Should I stay or should I go? Predicting dating relationship stability from four aspects of commitment. J. Fam. Psychol. 24:543-550.

Ridley, C.A., S.R. Jorgensen, A.G. Morgan, and A.W. Avery. 1982. Relationship enhancement with premarital couples: An assessment of effects on relationship quality. Amer. J. Fam. Ther. 10(3):41-48.

Rihn, A.L., C. Yue, B. Behe, and C. Hall. 2011. Generations X and Y attitudes toward fresh flowers as gifts: Implications for the floral industry. HortScience 46:736-743.

Sabatelli, R.M. 1988. Exploring relationship satisfaction: A social exchange perspective on the interdependence between theory, research and practice. Fam. Relat. 37:217-222.

Sassler, S. 2004. The process of entering into cohabiting unions. J. Marriage Fam. 66:491-505.

Schröder-Abé, M. and A. Schütz. 2011. Walking in each other's shoes: Perspective 
taking mediates effects of emotional intelligence on relationship quality. Eur. J. Pers. 25:155-169.

Schwartz, B. 1967. The social psychology of the gift. Amer. J. Sociol. 73:1-11.

Seaton, B. 1995. The language of flowers: A history. University Press of Virginia, Charlottesville, VA.

Society of American Florists. 2005. Insight floral trends consumer tracking study. 2 Jan. 2011 . <http://aboutflowers. com/about-the-flower-industry/consumertrends.html/>.

Society of American Florists. 2012a. Flower meanings and meanings of flowers. 28 Aug. 2012. <http://www.aboutflowers.com/ flower-a-plant-information-and-photos/ meanings-of-flowers.html>.

Society of American Florists. 2012b. Consumer trends on buying flowers. 28 Aug. 2012. <http://aboutflowers.com/aboutthe-flower-industry/consumer-trends. $\mathrm{html} />$.

Society of American Florists. 2012c. Valentine's Day floral statistics. 12 Feb.
2012. <http://aboutflowers.com/flowerholidays-occasions-a-parties/flowers-forvalentines/valentines-day-statistics.html/>.

Stackert, R.A. and K. Bursik. 2003. Why am I unsatisfied? Adult attachment style, gendered irrational relationship beliefs, and young adult romantic relationship satisfaction. Pers. Individ. Dif. 34:14191429.

Sternberg, R.J. 1986. A triangular theory of love. Psychol. Rev. 93:119-135.

Sternberg, R.J. 1997. Construct validation of a triangular love scale. Eur. J. Soc. Psychol. 27:313-335.

Tucker, J.S. and S.L. Anders. 1999. Attachment style, interpersonal perception accuracy, and relationship satisfaction in dating couples. Pers. Soc. Psychol. Bul. 25:403-412.

van Dulmen, M.H.M. and E.A. Goncy. 2010. Extending the actor-partner interdependence model to include cross-informant data. J. Adolesc. 33:869-877.
Vaughn, M.J. and M.E.M. Baier. 1999. Reliability and validity of the relationship assessment scale. Amer. J. Fam. Ther. 27:137-147.

Yim, C.K., D.K. Tse, and K.W. Chan. 2008. Strengthening consumer loyalty through intimacy and passion: Roles of customer-firm affection and customerstaff relationships in services. J. Mktg. Res. 45:741-756.

Yue, C., A. Rihn, B. Behe, and C. Hall. 2009. Consumer preference for flowers as gifts: Age segments, substitutes, and perceived risk. American Floral Endowment, Alexandria, VA.

Zeidner, M. and I. Kaluda. 2008. Romantic love: What's emotional intelligence (EI) got to do with it? Pers. Individ. Dif. 44:16841695.

Ziegler, C. 2007. Favored flowers: Culture and economy in a global system. Duke University Press, Durham, NC. 